ISSN(print): 2643-9840, ISSN(online): 2643-9875

Volume 04 Issue 06 June 2021

DOI: 10.47191/ijmra/v4-i6-23, Impact Factor: 6.072

Page No.- $837-842$

\title{
Mitigating the Devastating Effects of Covid-19 in Nigeria: The Place of Different Forms of Literacy
}

\author{
Richard C. Ihejirika ${ }^{1}$, Anthony E. Ogu ${ }^{2}$, Ugomma A. Agwuocha ${ }^{3}$ \\ ${ }^{1,2,3}$ Directorate of General Studies, Federal University of Technology, Owerri, Imo State, Nigeria
}

ABSTRACT: One of the global concerns in contemporary times is COVID-19 pandemic, otherwise known as corona virus, which, according to available records, had its origin in China. The pandemic, from all indications, has had devastating effects in the areas of health, economy, education and socialisation globally. Against this background, this paper reviewed the outbreak of the pandemic and its devastating effects globally and noted that so far, there had not been any known cure. Although efforts had been made by some nations and pharmaceutical outfits to develop vaccines, the paper observed that there had been a whole lot of controversies surrounding the efficacy and side effects of the vaccines, and as a result, many people had avoided making themselves available for the administration of the vaccines. In view of the foregoing, the paper argued that the corona virus, for now, has come to stay with humanity as HIV AIDS and other terminal diseases such as cancer, high blood pressure, diabetes and the like. And as a result, it is suggested that the Nigeria Government should, in addition to other measures already put in place to combat the deadly virus, ensure that the literacy rate of Nigerians as regards reading-writing literacy, media literacy and health literacy is accelerated so that Nigerians will be equipped and empowered to cope with the devastating effects of COVID-19.

KEYWORDS: COVID-19; mitigating; devastating; Nigeria; enhance; literacy; rural dwellers

\section{INTRODUCTION}

In late 2019, a deadly virus known as corona virus raised its ugly head in Wuhan, in the Republic of China. Before the Chinese could come to terms with the reality of the virus, it had already spread all over the globe, including Nigeria and became a pandemic. As expected, the World Health Organization (WHO) christened the virus "COVID-19" which means "Corona virus disease 2019", where 'CO' stands for corona, ' $\mathrm{VI}$ ' for virus and ' $\mathrm{D}$ ' for disease. In Nigeria, a corona virus disease case was confirmed by the Federal Ministry of Health on the $27^{\text {th }}$ of February, 2020 (https://ncdc.gov.ng>news>firstca...). The symptoms of the disease among other things include:

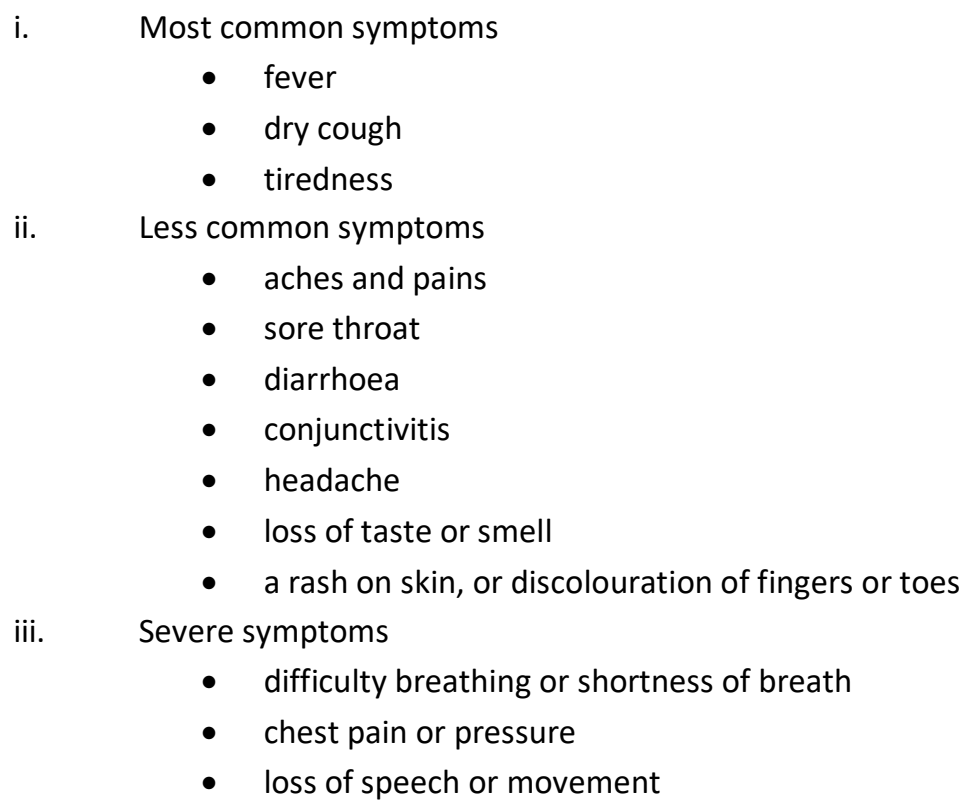




\section{Mitigating the Devastating Effects of Covid-19 in Nigeria: The Place of Different Forms of Literacy}

When an individual is infected with the virus, it takes between 5-14 days for the symptoms to manifest. Dr Osagie Ehanire, the Hon. Minister of Health listed the precautions that must be observed by all and sundry to avoid contracting the disease as follows:

i. Wearing face mask

ii. Regular hand wash

iii. Maintain social distance

iv. Persons with persistent sneezing or cough to stay at home or keep a social distance

v. People to maintain respiratory hygiene

vi. Stay at home if you feel unwell with symptoms like fever, cough and difficulty in breathing

(https.//ncdc.gov.org/news/227).

The effects of the pandemic have been devastating globally, Nigeria inclusive. The health, social, economic and educational sectors of nations of the world have not been the same again. For instance, in the area of health, according to WHO, globally as of 4:43pm CEST, 9 May, 2021, there have been 157,289,118 confirmed cases of COVID-19, including 3,277,272 deaths. In Nigeria in particular the statistics show that there have been 165,370 confirmed cases, including 2,065 deaths. By this statistics, it is obvious that the health of the people of the world is under serious threat.

Similarly, the economy of the world has been undergoing serious decline. Following the lockdown occasioned by the pandemic, many business outfits, including companies, industries, ministries, parastatals and even markets were either closed down or the workers were compelled to work from home. Consequently, many people lost their jobs or have their businesses closed down and are now living from hand to mouth. The social lives of the people equally had their share of the devastation by the pandemic. In the first instance, people were forced to stay indoors in order to avoid contracting the disease. Secondly, social functions such as marriages, burials, meetings or any form of gathering were completely banned with severe sanctions against offenders. Faith organisations were not left out. Religious worships in churches and mosques were equally banned. For educational institutions, there was total closure of schools, and the much that could be done was on-line teaching and learning for institutions that could afford it.

Following the unbearable devastating effects of COVID-19, Nigerian Government had no choice but to look inwards and came up with measures that would not only ameliorate the effects but also help to arrest the wide spread of the deadly disease. As a result, the Government set up a Presidential Task Force (PTF) and charged it with the responsibility of devising measures for tackling the pandemic head on. First, the PTF embarked on intensive and extensive creation of awareness on the dangers of the virus and measures people could embark upon in order to keep safe. These the PTF did, using the print, electronic and social media.

In addition, the PTF set up isolation centres for people who had contracted the virus. All these efforts were geared towards minimising the spread of the disease since there has not been any known cure. However, there was glimmer of hope when WHO acknowledged the fact that vaccines had been developed by some countries and pharmaceutical organisations and went ahead and approved the administration of the vaccines. Unfortunately, the vaccines had been greeted with series of controversies. While some people, nations and organisations have admitted to use the vaccines and had gone ahead to administer them on people, some others on the other side of the divide have insisted that the vaccines are not safe for human use and have bluntly refused to accept the vaccines let alone administer them on people.

Against the backdrop of the raging controversies and the fact that there has not been any known cure for the virus for now, the situation appears to be as bad as the fact that COVID-19 has come to stay with humanity as HIV and AIDS, and other terminal diseases such as cancer, high blood pressure, diabetes to mention but a few. Consequently, it has become absolutely necessary to look inwards in order to come up with other measures that would go a long way in mitigating the overwhelming effects of the corona virus. It is in recognition of this fact that this paper aims at proposing that enhancing the literacy rate of Nigerians would go a long way in ameliorating the dangerous effects of pandemic. In doing so, we shall in this paper explain literacy in detail, pointing out its different types and discussing how they can contribute meaningfully in mitigating the devastating effects of the deadly corona virus. In addition, we shall suggest effective ways of realising the different literacy forms in Nigerian context in order to use them as tools of ameliorating the raging devastating effects of the pandemic.

\section{THE CONCEPT OF LITERACY}

The early man as the forebear of humanity was raw and close to nature. He made due with his limited natural intelligence and was able to satisfy his basic needs: food and shelter. However, as time went on, the dynamism of society started to play out and the early man and his offspring started to transform from one stage to another according to the dictates of the societal circumstances. The gradual emergence of civilization in the evolution of man was a remarkable watershed. At that point in history, the needs of the descendants of the early man began to widen and as expected, man has no choice but to embrace the unavoidable societal changes in order to be relevant but went ahead to adjust himself in order to cope with the circumstances of his time. 


\section{Mitigating the Devastating Effects of Covid-19 in Nigeria: The Place of Different Forms of Literacy}

One of the offshoots of civilisation is literacy. By the time the early man metamorphosed to modern man, his basic needs ultimately changed, and his basic needs expanded to include literacy, which is one of the end products of education. From the traditional point of view, "literacy simply means ability to read and write". But given the dynamism of the society and advancement in science and technology, literacy concept has got expanded meanings to the extent that today, we read and hear such concepts as reading and writing literacy, media literacy, health literacy, computer literacy, mathematics literacy, technology literacy, computer literacy and so on. It is in recognition and appreciation of the ever-increasing expanded meaning of literacy that UNESCO (1962, p.18) stated that:
A person is literate when he has acquired the essential knowledge
and skills which enable him to engage in all those activities in which
literacy is required for effective functioning in his group or community, and whose attainments in reading, writing and arithmetic makes it possible for him to continue to use those skills towards his own and community's development and for active participation in the life of his country.

In order to still accommodate the extended and changing meaning of literacy and throw more light to its understanding and appreciation, UNESCO (1965) has the following to say about literacy:

It is a way of preparing men for social, civic and economic roles, especially when this goes beyond the rudimentary literacy training of reading and writing but embraces general knowledge for work, increased productivity, a greater participation in civic life, better understanding of the surrounding world and ultimate openness to basic human culture (p.3)

Okedara (1981) corroborates UNESCO's concept of literacy and describes one who is literate as a person who has acquired the essential knowledge and skills which enable one to participate in all literacy-based activities and whose attainment in literacy skills facilitates one's use of these skills for his own and community development.

In line with the argument on the extended meaning of literacy as being advanced by UNESCO and Okedara (1981), we have identified three forms literacy that are relevant and capable of contributing immensely in mitigating the overwhelming and deadly effects of COVID-19, especially in Nigerian context. The forms of literacy include:

i. Reading-writing literacy (traditional concept of literacy)

ii. Health literacy

iii. Media literacy

We shall go further to expound these literacy types and articulate how they can be enhanced and deployed to mitigate the effects of the pandemic since for now, there is no permanent cure.

\section{Reading-Writing Literacy}

The reading-writing literacy, otherwise known as traditional literacy, simply means the capacity an individual has which enables them to read and write. In the modern times that is characterised by civilization, science and technology, it is essential bedrock for human development and advancement. It is based on this premise that Ihejirika (2014, p. 591) states that:

It is a skill that empowers an individual to cope with the

sophisticated nature of the modern time that is driven

by education, science and technology and enables him

to contribute meaningfully to national development.

Reading-writing literacy is not an end itself but a means to an end. It is the most important skill required for a successful education programme, whether formal or informal. In addition, reading-writing literacy is a socialisation process which refines an individual and equips them with the necessary skills that would enable them to overcome the overbearing influences of ignorance, superstition, poverty and diseases that thrive in a state of illiteracy and which have the capacity to stifle any efforts geared towards any development agenda, be it individual, community, state, national or international level (Ihejirika 2014, p. 591). Reading writing literacy is an agent of civilization. "It creates room for establishment of income generation and by extension raises the standard of living of an individual and enhances economic growth and technological advancement of a nation, including effective participation in civic responsibilities, agricultural practices and other human endeavours that promote human existence (Ihejirika 2014 pp. 591-592). 


\section{Mitigating the Devastating Effects of Covid-19 in Nigeria: The Place of Different Forms of Literacy}

A pertinent question at this juncture is: In the face of the prevailing devastating effects of COVID-19, where does reading-writing literacy come in with regard to mitigating the effects. Obviously, "my people perish for lack of knowledge," according to the Holy Bible. In the present circumstance, the illiterate people stand the risk of suffering the effects of the COVID-19 most because of some obvious reasons. First, they cannot access information on the pandemic that abounds in the print, electronic and social media. Secondly, because of their level of ignorance occasioned by illiteracy, they may not appreciate the relevance of COVID-19 precautions and protocols and may end up not observing them. In the event of contracting the virus and prescription is made, an illiterate person may likely abuse the prescription and dosage of the drugs if a literate person is not around to guide them. An illiterate person relies so much on unfounded rumours because they do not have access to authentic information.

In Nigeria, the successive governments appreciate the need for mass literacy as a weapon for fighting disease, ignorance, hunger and poverty. As a result, government has come up with one literacy programme of the other at one time or the other in order to achieve appreciable level of literacy among the citizenry. For instance, there have been literacy programmes as Universal Primary Education (UPE), Universal Basic Education (UBE), Adult Literacy Programme (ALP), and Nomadic Education among others. In addition, some state governments have gone extra mile to introduce free education at all levels of education to ensure that the citizenry have qualitative education, which obviously is the surest process of attaining literacy skills. In spite of all these efforts, it is regrettable to note that the level of illiteracy in Nigeria, especially in the rural setting is nothing to write home about. For instance, the Editorial of This Day Newspaper of $1^{\text {st }}$ August, 2019 reported that 33\% of Nigerians are illiterate. Also, UNESCO (2005) stated that illiteracy rate in Nigeria is as follows:

Men $\quad-25.6 \%$

Women $-40.6 \%$

Ages 15-24

Men $\quad-9.3 \%$

Women $\quad-13.5 \%$

If these reports are anything to go by, they suggest that many Nigerians are vulnerable to the effects of CCOVID-19 as a result of illiteracy.

Now that it is obvious that corona virus has come to stay with us, government should intensify efforts to enhance the rate of literacy in Nigeria so that the citizens will be equipped with the reading-writing literacy skills, which will in turn help them to cope with the devastating effects of the pandemic. In order to achieve this purpose, the following suggestions are inevitable:

i. $\quad$ Free basic education should be sustained in all states of the federation.

ii. The decay in infrastructure in public primary and secondary schools should be radically addressed as a matter of urgency.

iii. All barriers against girl-child education should be eliminated at all cost.

iv. Teachers at primary and post-primary schools should be properly motivated by enhancing their salaries and sponsoring them regularly to attend seminars, workshops, conferences in order to update and upgrade their professional knowledge and skills.

v. Adult education centres should be revisited and made more functional and attractive.

vi. Adult education centres should be brought close to the adult learners. Every political ward should have a centre.

vii. The adult learners should be provided with free learning materials and free refreshment during each contact.

viii. Graduates of adult education programmes should be given paid employment that is within their reach to serve as an incentive to them.

\section{Media Literacy}

Twenty-first century has been described as a digital age. By this development, sources of information are no longer limited to the traditional media: TV, radio, newspapers and magazines, rather, the sources have been diversified as a result of the explosion in the ICT world. Today, we talk about social media, viral videos, video games, text messages, advertising and more. With the traditional and modern source of information put together, humanity appears to be on information high way and as a result, it is becoming increasingly difficult for individuals to manage effectively the information they are exposed to on daily basis. This development has created room for the emergence of media literacy, which is why it has been described as a twenty-first century approach to education.

Media literacy has been defined as "the ability to identify different types of media and understand the message they are sending." It provides information on how best to access, analyse, evaluate and create messages in a variety of forms ranging from print, video to internet. Media literacy creates awareness with regard to the role of media in a society as well as the necessary skills of inquiry and self expression essential for people in a society. Media literacy helps individuals to be knowledgeable, literate and critical in all forms of media to enable them to manage and control the interpretation of what they read or hear instead of allowing 


\section{Mitigating the Devastating Effects of Covid-19 in Nigeria: The Place of Different Forms of Literacy}

the interpretation to control them. "To become media literate is not to memorise facts or statistics about media, but rather to learn to raise the right questions about what you are watching, reading or listening to" (https://www.medialit.org/read).

The fact that we are in a digital age has made it possible for individuals to write whatever that comes their way and put across to the public through any medium accessible to them even when the information may not be true or authentic. On the other hand, a good number of people tend to swallow hook, line, and sinker whatever they hear or read from the media. In many cases, some will even go all out to act on information they have read or heard without questioning the source or authenticity. There is no doubt that people who relate to media information in this manner are suffering from media illiteracy. From all indications, media illiteracy is one factor that has worsened the devastating effects of COVID-19 in Nigeria. This is so because the media have been awash with information relating to the virus. Although some of the information may be authentic, especially those coming from government, some of them, no doubt, are false and fabricated. For the fact that many Nigerians are media illiterate, many pieces of information on COVID-19 that come their way have been treated as such. A typical example is the propaganda that is being peddled about the COVID-19 vaccines and their administration. Today, many people have bluntly refused to take the vaccine because of the rumours making round about the adverse effects of the vaccines. This unfortunate trajectory should be an eye opener on the part of the Nigerian government. While the government is neck-deep in finding solutions to what would mitigate the effects of the pandemic, efforts should be made to ensure that a good number of Nigerians are media literate. To be able to achieve this objective, the following suggestions have become necessary:

i. Media literacy should be facilitated through various media for the benefit of reading-writing literate persons. It is obvious that not everybody that is reading-writing literate is also media literate. As a result, efforts should be made by government, academic institutions, and non-governmental organisations (NGOs) to organise seminars, workshops and conferences on media literacy for the benefit of the citizens.

ii. National Orientation Agency (NOA) should carry out intensive campaign on mass media literacy, especially in the rural areas. This campaign should be done periodically in the form of town hall meetings.

iii. A long term solution to media illiteracy is to integrate it in the curricula of primary, post-primary and tertiary institutions by the education authorities. At the primary and post-primary schools, it should be made a compulsory subject while at the tertiary institutions, it should be taught as a general studies course, which every student must offer and pass before graduation.

\section{Health Literacy}

Health is one of the basic concerns of any living person whether literate or illiterate. The high premium placed on health has necessitated the emergence of health literacy. It is one of the expanded meanings of traditional literacy. With regard to the meaning of health literacy, some scholars and organisations have come up with some definitions. For instance, Deann Jepson, the Senior Programme Director at Advocates for Human Potential, defines health literacy as "the ability of patients, caregivers, family members and the public to understand what doctors and other healthcare providers are communicating. Similarly, Akela Blue, Health Communications Consultant at Be Health Literate opines that "health literacy is how we receive, interpret and act on health information." According to him, being health literate allows us to make the best decisions regarding our health. Also, Centre for Disease Control (CDC) states that health literacy is "an individual's ability to obtain, communicate, process and understand basic health information and services." It equally adds that just as reading literacy gives you skills to understand and use written information, health literacy refers to the skills you need to understand and make decisions about your health. Against the backdrop of the foregoing definitions, it goes without saying that health literacy is a necessary skill for all living persons since every individual has the responsibility of taking care of their health condition.

Regrettably, to mention health literacy in Nigerian context for now sounds strange to a good number of people. The reason is that many Nigerians may not have heard or read about it let alone knowing what it stands for and putting it into practice. On the part of the government, much has not been said about health literacy and there has not been any articulated programme by the government geared towards ensuring that the citizenry are health literate as it is usually done in the case of reading-writing literacy. Consequently, the reality of the day is that many Nigerians are health illiterate and this situation might be partly responsible for the poor health condition many Nigerians pass through. It is as a result of this deficit in the health sector in Nigerian context that this paper strongly advocates mass health literacy as one of the surest ways of mitigating the devastating effects of COVID-19 in the present circumstance. To be able to achieve this all important objective given the prevailing health, economic and social challenges occasioned by the pandemic, the following suggestions should be strictly adhered to:

i. The government should as a matter of priority and urgency, come up with well-articulated feasible programmes aimed at achieving mass health literacy as it is being done in the case of reading-writing literacy. In doing so, the rural areas should be a major target. 


\section{Mitigating the Devastating Effects of Covid-19 in Nigeria: The Place of Different Forms of Literacy}

ii. The hospitals, medical practitioners, public health practitioners, healthcare givers and related health service providers should go beyond diagnosing and prescribing drugs and place much emphasis on preventive measures.

iii. Hospitals should use their public health officers to educate patients on health literacy. No other institution can do it better than hospitals because they create room for the gathering of patients more than any institution.

iv. National Orientation Agency (NOA) should carry out vigorous campaign for health literacy, using medical practitioners as resource persons. In carrying out this campaign, the rural areas should be a major target.

v. Most importantly, education authorities should integrate health literacy in the primary and post-primary school curricula and make it a compulsory subject. At the tertiary level of education, it should be taught as a general studies course which must be passed by every student before graduation.

\section{CONCLUSION}

There is no gainsaying the fact that COVID-19 appears to be the worst disease that has kept all parts of the world on their toes at the same time in the recent past. It has, no doubt, devastated the health, social, economic and educational sectors of all nations without an exception. Although nations of the world, including Nigeria, have, in their different ways, come up with diverse measures to combat the virus, it appears that all the efforts so far put in place seem to be an exercise in futility since the disease has kept on raging. Without sounding pessimistic, it is our opinion in this paper that COVID-19 has come to stay with humanity just as other terminal diseases as HIV AIDS, cancer, diabetes, high blood pressure and the like. Therefore, while we urge the government of Nigeria to step up all the measures already put in place to mitigate the virus, it is also suggested that the government should as a matter of urgency, put the necessary machinery in the appropriate place to promote mass reading-writing literacy, media literacy and health literacy among the citizenry. By so doing, it is hoped that the people of Nigeria will not only be equipped but also empowered to cope with the devastating effects of COVID-19.

\section{REFERENCES}

1) Ihejirika, R.C. (2014). Integrating extensive reading in the school curriculum: An effective strategy for enhancing and sustaining literacy in Nigeria. Interdisciplinary Journal of Contemporary Research in Business, 5(9), pp. 591-592.

2) Okedara (1981). The impact of literacy education in Ibadan, Nigeria. Ibadan: University of Ibadan Press.

3) This Day Newspaper (2019, August 1). Editorial

4) UNESCO (2005). Indicators on Illiteracy. Retrieved October, 2008 from htt://www.uis.unesco.org.

5) UNESCO (1962). Committee Report on Adult Education. Paris: UNESCO Press.

6) UNESCO (1965). Report of Council of Ministers of Education Conference on Adult Education in Teheran. Paris: UNESCO Press

7) (https://ncdc.gov.ng>news $>$ firstca...)

8) (https.//ncdc.gov.org/news/227)

9) (https://www.medialit.org/read) 